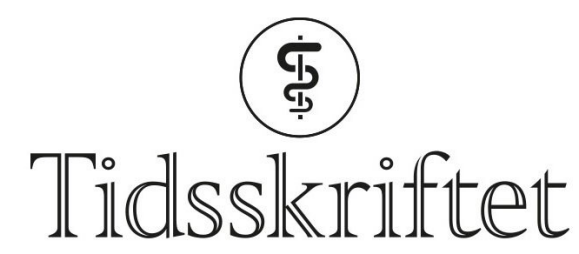

DEN NORSKE LEGEFORENING

\title{
Ny tids tale
}

MINILEDER

\section{ARE BREAN}

Sjefredaktør

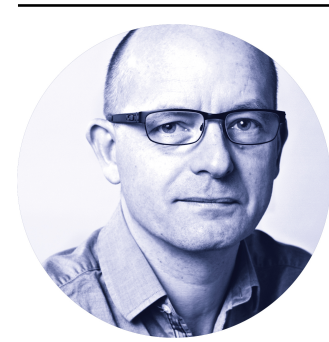

Samhandlingsreformen har ikke fungert godt nok. Fremdeles bygges sykehus for små, og mange kommuner har ikke ressurser til å ta imot de som skrives ut.

Nå foreligger regjeringens løsning på problemet. Et av hovedgrepene i den kommende Nasjonal helse- og sykehusplan er nemlig 19 såkalte «helsefellesskap» over hele landet. Disse skal organiseres på tre nivåer i en rekke nye møter: Partnerskapsmøter skal «bestemme strategisk retning», strategiske samarbeidsutvalg skal «utvikle tjenester» og faglige samarbeidsutvalg skal «utvikle prosedyrer og pasientforløp». I tillegg skal det være hyppige kontaktmøter samt et nytt sekretariat, som skal «sikre åpenhet og legitimitet $\mathrm{i}$ beslutningsprosessene, og oppnå konsensusbeslutninger». Fastlegene skal pålegges å være med på alle møtenivåer. Det følger ikke penger med nyordningen.

Det er altså ikke flere hender og flere senger som skal hjelpe pasienter som faller mellom alle samhandlingsstoler, men mer byråkrati og mer feiende flott nytale. Og hjelperne som allerede finnes, skal sitte i enda flere møter. Kommuner og sykehus skal gå fra å være "parter» til å bli "partnere», uttalte helseminister og statsminister under lanseringen. Hvor pasientene skal gå, ble det ikke sagt noe om.

Publisert: 4. november 2019. Tidsskr Nor Legeforen. DOI:10.4045/tidsskr.19.16.01 (C) Tidsskrift for Den norske legeforening 2020. Lastet ned fra tidsskriftet.no 